\title{
The Role of Social Movements in the Re-Configuration of Youth Transition Regimes: The Biography of an Unemployed Graduates Activist in Morocco
}

\section{Christoph Schwarz}

\section{Introduction}

For twenty-five years, North Africa and West Asia (NAWA) has been the region with the highest youth unemployment rates worldwide, and developments since the so-called Arab Spring have hardly changed those numbers (Kabbani 2019). Before 2011, the situation of these unemployed has been mainly discussed from a rather technical perspective that has focused on policies and institutions, and has problematized young people's situation using the notions of "stalled youth transitions" (Salehi-Isfahani 2008; see also Dhillon et al. 2009), and, more precisely waithood (Singerman 2007, 2011). ${ }^{1}$ However, few scholars have written about the collective strategies of the unemployed themselves (Emperador Badimon 2009a, 2011b; Schwarz 2017, 2018).

In this chapter, I analyze the Unemployed Graduates Movement in Morocco from a youth transitions perspective that considers young people's agency. This movement, which has been mobilizing since the early 1990s, is a particularly instructive example of how young people negotiate their own transitions to adulthood within an authoritarian regime. For these purposes, people are defined as "young" if they have not yet attained the economically necessary assets required for adult status according to the hegemonic social norms: the resources to provide for a family of their own.

C. Schwarz $(\bowtie)$

Frankfurt a. M., Germany

e-mail: christoph.schwarz@staff.uni-marburg.de

C The Author(s) 2021

R. Ouaissa et al. (eds.), Re-Configurations, Politik und Gesellschaft des Nahen

Ostens, https://doi.org/10.1007/978-3-658-31160-5_12 
In the first section, I will briefly discuss theoretical perspectives to analyze the phenomenon, and suggest applying the concept of "youth transitions regimes" (Walther 2006). The "regime" notion problematizes youth as a political issue, i.e. as the result of power relations, since it focuses on the structures and institutions that mold transitions to adulthood. However, by methodologically adopting a contextualized life-course approach (Nilsen et al. 2018), I intend to identify the dynamics within the Moroccan youth transitions regime from a bottom-up perspective, i.e. from the perspective of activists who contest it. In line with the Re-Configurations approach, I aim to reconstruct patterns of conflict and cooperation between protesters, authorities, and institutions, and thus take into account the interrelation of agency and structure in order to bring to the fore the specific "order of change" (Elias 1970, p. 149).

In the second section, I will introduce and contextualize the Moroccan Unemployed Graduates Movement against the backdrop of the re-configuration of the country's social contract. From 2014 to 2017, I conducted seventeen interviews with activists of the movement, some of them life-story interviews, others more thematically focused. In the third section, based on this material, I will introduce as an example the life story of one of the movement's coordinators in order to illustrate the key dynamics of activists' life-courses and to discuss the movement's development since 2011. This example will be complemented by findings from other interviews with activists and the general literature. On this basis, the chapter also discusses generational and spatial dynamics, i.e. the center-periphery relations that underly the movement and their moral economy (Thompson 1971), i.e. the way they draw on an older social contract-that of the development state under Hasan II-to justify their present claims. Last but not least, these interviews also illustrate that the 2011 "Arab Spring" protests resulted in a re-configuration of the Moroccan youth transitions regime, in the sense of a disruption of the dynamic ritual of negotiations between the unemployed graduates and the Moroccan authorities. I will conclude with a brief discussion of the results and point to remaining open questions.

\section{Life-Courses in Youth Transition Regimes}

A rift between two approaches has long structured the field of youth studies: the "youth transitions" and the "youth cultures" approaches (MendozaDenton and Boum 2015). Whereas the former emphasizes the institutional and socio-economic milestones on the path to adulthood, the latter focuses on the subjective meanings young people attribute to their status and status changes as well 
as their cultural strategies for dealing with "being young" in a particular social place. Roughly speaking, the "transitions" perspective has focused more on policies and structures, whereas the "culture" perspective has aimed to reconstruct young people's agency and the subjective meaning they attribute to their status as "youths." In one of the most pointed criticisms, Wyn and Woodman (2007) argued that the transitions perspective is inherently flawed, since its characterisations all rest on the assumptions that (a) there exists a normative transitional process, from which some young people deviate; (b) youth is a linear process or position on a life-course; and (c) culture, economy and politics simply add 'flavour' or context to the development process. In the main, the literature on transitions draws implicitly on popular conceptualisations of generations, in which the Baby Boomer generation has become the implicit norm. The transitions of this generation (from school to work, leaving home, establishing nuclear families) have become the standard timeline against which subsequent generations are judged. This timeline calls young people's life patterns and choices into question through established assumptions about what 'ought to be' (Wyn and Woodman 2007, p. 498).

Accordingly, youth policies that apply a youth transitions perspective are often inconsistent, since they draw on a stereotypical idea of 'youth'. Instead, Wyn and Woodman argue for a generational approach that departs from the differences between social generations. In a response to this criticism, Roberts (2007) argues that generational and transition approaches have, in fact, been inseparable since the onset of research. The current consensus, among transition researchers-that transitions have been prolonged, de-standardized/individualized, and are often reversible 'yoyo' transitions - is itself the result of an implicit application of generational differences. By now, many studies are instead using transitions and cultural perspectives as complementary, and many transitions researchers concede the need to take young people's subjectivities into account to a greater degree (Furlong et al. 2011).

In this chapter, I will apply a "grounded" transitions perspective that refrains from developmentalist and psychologist tenets, but is situated in the framework of a life course, or biographical perspective. In other words, I will adopt a "contextualized" life course approach in the sense of Nilsen, Brannen, and Chelsom Vogt (2018, p. 85):

What characterizes a contextualist life course approach is its sensitivity to historical and spatial contexts. Studies from this perspective do not seek to formulate "laws" about how transitions happen that transcend time and place. Life course transitions, included the transition from youth to adulthood, are studied with reference to the historical period and contextual features of particular societies and 
groups that relate to social class, intergenerational relations, gender and ethnicity in which individuals are situated.

In this vein, I argue that a transitions perspective remains important in order to reconstruct the structural processes that reproduce social inequality along dimensions besides the generational divide, such as class position, gender, or geographical situatedness; the latter is particularly important in a country like Morocco, which exhibits the highest rural-urban divide in the region (World Bank 2011). Such a grounded and contextualized transitions perspective allows us to identify how these divisions translate into typical turning points in individual life courses, and most probably result in the intergenerational reproduction of certain social positions. Likewise, a transitions perspective seems imperative in order to reconstruct how socio-economic constraints, but also hegemonic symbolic representations and the acquisition of status symbols of "youth" and "adulthood," impinge on young people's trajectories, decisions, and political strategies.

The concept of regime of youth transitions, coined by Andreas Walther (2006), seems particularly useful for examining the political nature of these transitions: How are youth and adulthood socially and politically defined, and by whom? What notion of citizenship is central to the social contract within which transitions to adulthood are institutionally organized and negotiated? Discussing such questions with a regime terminology results in an analysis that looks at power structures and political actors and does not restrict itself to a merely technical policy discourse.

Drawing on Esping-Andersen's (1990) and Gallie and Paugnam's (2000) typologies of welfare regimes in Europe, Walther defines 'regimes' as existing institutional settings that have a history structured not only by conflicts and the interests of specific social actors but also by the set of values and interpretations they constantly reproduce. Institutions and concepts merge into what is conceived of as 'normal' in a given context, which also includes a 'normal' relation between individual entitlements and collective demands. Herein, cultural and social patterns are also concerned with influencing individuals' biographical orientations. (Walther 2006, p. 124).

Translating the welfare regime concept to that of a "youth transition regime" also requires the analytical inclusion of schooling and training, as they relate to (gendered) concepts of work (and profession), and the respective structures of employment and unemployment benefit programs. Using such ideal types and clustering different national systems necessarily leads to certain generalizations. The interpretative value of this model represents "a heuristic compromise of medium range validity. The strength of such a model lies in referring to the 
'Gestalt' of the different models through which young people's lives are regulated" (Walther 2006, p. 125).

Although the regime notion suggests a clear focus on institutions and policies, Walther stresses that his concept also aims to analyze the interplay of structure and agency. Hence, he also refers to young people's biographical orientations in relation to their youth transition regimes. However, the youth transitions regime literature is still lacking an examination of politics from below, i.e. organized, collective, political strategies of young people in particular regime settings, for example in the framework of social movements. In the following, I aim to offer one such example.

\section{Morocco: The Unemployed Graduates Movement and Its Historical Context}

So far, there has been no systematic analysis or classification of the Moroccan youth transitions regime, and it is beyond the scope of this chapter to provide one. Instead, I am going to focus on one particular transition segment, the transition from university to work, and on the social struggles over how this transition is organized. If the education sector is key to any youth transitions regime, it is particularly so in Morocco, where in recent decades a very insightful negotiation of transitions at this particular juncture evolved between two actors: the monarchy and the government, on one side, and the unemployed university graduates movement, on the other.

\section{The Youth Transitions Regime of the Development State}

The diplômés chômeurs-or unemployed graduates-movement developed against the backdrop of a successive shift of the Moroccan social contract and its respective youth transitions. Whereas the decades after the country's independence in 1956, under the reign of Mohamed V (r. 1957-1961) and the first two decades after Hassan II (r. 1961-1999) took the throne, the monarchy's policies followed the logic of a development state. As in many other nation states in the region, the government, in order to consolidate its power, expanded the public sector, invested heavily in education and public administration, and granted citizens certain social privileges and rights in exchange for their loyalty. In a process termed 'Moroccanization', the makhzen ${ }^{2}$ - the monarchy's own network of patronage, repression, and control—brought many economic activities under its control and allotted resources to its supporters (White 2001). For university graduates, this meant a guaranteed position as a civil servant after obtaining their diploma. 
The flipside of the offer of economic benefits for loyalty was political repression and brutal human rights violations. The reign of Hassan II is often referred to as the 'Years of Lead', since those who refused loyalty to the regime- such as left-wing, democratic, or Amazigh ${ }^{3}$ activists or the student activists of the National Moroccan Student Union (UNEM, Union National des Étudiants Marocains) — were often arbitrarily detained, tortured, imprisoned, killed outright, or 'disappeared' to secret prisons such as the notorious Tazmamart (Vermeren 2006; Miller 2012; Hachad 2017; Menin 2019).

\section{Redefining the Social Contract}

The regime financed much of its expansion of the public sector, and the employment guarantees that came with it, within the framework of a rent economy. In this case, the natural resource from which to generate rents on the world market is phosphate, of whose global reserves Morocco holds around 40\%, making it the world's most important exporter (Vaccari 2009). The heavy investment in the public sector came to a halt by the end of the 1970s. In 1975, the monarchy took control of Western Sahara, which resulted in heavy investments, both civilian as well as military since it now engaged in an armed conflict with the Polisario movement, which claimed the territory's independence. In addition, phosphate prices began to drop. This meant a reduction in government revenues, which could no longer cover the exorbitant public expenditures. Faced with massive fiscal instabilities, the monarchy sharply reduced public spending, which resulted in an increase in unemployment rates. At that time, major "bread riots" broke out in Casablanca in 1981. In 1983, Morocco had to agree to an International Monetary Fund (IMF) and World Bank structural adjustment program (SAP). This SAP included a devaluation of the Moroccan currency, the dirham, liberalization of trade, and further public budget cuts (White 2001, p. 32).

Bogaert summarizes the monarchy's strategy as a successive replacement of the old social contract of the development state with a new one, in which people were "responsibilized" and encouraged to seize the opportunities of the (free) market. State power had to be redeployed and reorganized, not only to exploit strategic locations and redesign urban skylines but also to create neoliberal citizens (self-reliant, entrepreneurial, individualized) and facilitate their integration into the formal market ("inclusive growth"). (Bogaert 2018, p. 166).

For university graduates, this meant that they could no longer count on a post as a public servant. Whereas between 1970 and 1977, university enrolment had tripled and the number of public servants had grown at an annual average rate of $5,5 \%$, the unemployment rate among university graduates rose from $6,5 \%$ in 1982 to $26 \%$ in 1991 and $40 \%$ in 2002 (Bogaert and Emperador Badimon 2011). 
This rate tended to be higher among those with advanced degrees (Cohen and Jaidi 2006, p. 139), which is why Bennani-Chraïbi (2000, p. 143) even considered the integration of the educated urban young to be "the most pressing problem in Morocco today". Since this assessment from two decades ago, things even have deteriorated, particularly since 2010, with unemployment rates of over $20 \%$ for people aged between 15 to 24 as the national average, and even over $45 \%$ in urban regions (Medias24 2017; World Bank 2011).

Since Mohamed VI's ascension to the throne, in 1999, educational reform has been one of the regime's key priorities. Morocco was the first country in the NAWA region to introduce the Bachelor, Master, PhD system in its public universities (Kohstall 2012).

\section{The Moroccan Unemployed Graduates Movement}

First protests of unemployed university graduates date back to the early 1990s. In 1991, activists founded the world's first trade union-like organization for unemployed graduates, the National Association of Moroccan Unemployed Graduates (ANDCM, Asociation Nationale de Diplômés Chômeurs du Maroc) (Sater 2007, p. 97). The roots of the movement clearly developed out of university students' unions, like the UNEM, and the first activists shared a leftist ideology. However, they were frustrated with "traditional ideological politics" that had not brought any socio-economic improvements; meanwhile, their own and the previous generations' experiences of the 'Years of Lead' had made them careful to avoid repression by the state forces. Against this backdrop, they opted for a form of "apolitical mobilization" (Emperador Badimon 2011b) focusing on one single subject: the right to employment in the public sector, and, concomitantly, opposition to recruitment through nepotism and patronage networks.

Among their central reference points were Articles 12 and 13 of the 1996 constitution, which state that all citizens have "equal rights in seeking education and employment." (13) ${ }^{4}$ and that "Opportunities for employment in public offices and positions shall be uniformly open to all citizens" (12); and two ministerial decrees, which guarantee direct employment into public service after completing a Master's degree (Cohen and Jaidi 2006; Bogaert and Emperador Badimon 2011).

The focus on the single subject of employment and the abstention from demands for any further political changes resulted in an approach that was very open-ended ideologically and that, from the very beginning, allowed Leftists, Islamists, Amazigh activists, and non-partisan graduates to come together for a common cause. This subverted the regime's strategy of playing different actors against each other. 
At first, activists confined themselves to sit-ins and hunger strikes in the relatively protected environments of the offices of supportive labor unions. However, after some years of consolidation and organizational expansion into more remote regions, the ANDCM adopted more public tactics, culminating, in 1995, in a nine-and-a-half-month sit-in - the longest in Moroccan history-outside the Ministry of Education. Ever since, their actions have been mainly street-based: demonstrations and sit-ins in front of the parliament in the country's capital, Rabat, demanding negotiations with the Minister of Labor, or, in case of repression, with the Minister of the Interior (Sater 2007, p. 94; Rachik 2010, p. 26; Emperador Badimon 2011b).

Within several years, a certain political ritual evolved: when protests intensified, the government, employing methods of both repression and cooption, would regularly negotiate with the protesters and directly employ some of them in the public sector. The protest coordinators would in turn monitor their members, using lists of participation, to make sure that only those who regularly and actively participated in the protests were employed. Activists were given tokens they had to return to their local coordinator after the demonstrations (Emperador Badimon 2007, 2009b, 2011b; Bogaert and Emperador Badimon 2011). In some committees, those activists who exposed themselves to a higher degree to police violence, for example by forming the front row during sit-ins, would be given a higher ranking on the coordinators' list. ${ }^{5}$ After successful negotiations and ensuing employment, the respective protest groups would dissolve, only to be replaced soon enough by new cohorts of fresh graduates who could not find public-sector jobs. In the course of this process, the structure of the ANDCM was successively side-lined and replaced by decentralized local chapters that in recent years organized not only based on region, but also on degree level, and thus became somewhat more exclusive.

At the time of my research, from 2014 to 2017, the activists would gather in groups (according to their local chapters) up to three days every week in a park situated $250 \mathrm{~m}$ from the Moroccan Parliament in Rabat. Usually, they would gather in circles and discuss organizational and strategic questions. When they decided they were enough activists for a significant protest, they would form a disciplined demonstration, many of them dressed in vests bearing their committees' logos, and take to the streets. Organizers wearing special vests would walk alongside the demonstration and maintain order. In front of the parliament, the anti-riot brigades of the police would usually dissolve the demonstration. The activists applied a tactic called "provoke and run": they ran from the police, then hid by mingling with passers-by on the avenue, only to return as soon as possible in smaller groups to the area outside the Parliament, where they would again take 
out their banners and vests and recommence shouting and singing slogans until the police returned and chase them again.

In the following, I will take a closer look at the processes of engagement in the movement by introducing the life story of one of the activists, which I complement with findings from other interviews and the general literature.

\section{An Activist Biography}

Omar, ${ }^{6}$ who was in his early thirties at the time of the first interview in 2014, grew up in a small village in the Rif Mountains. He holds a BA and a MA in English Literature and was pursuing his PhD. Omar has five brothers and two sisters. His father, a tailor, had died when Omar was still a child. He emphasized that this was very difficult not only psychologically, but also socioeconomically. Most of his fellow students and colleagues remained financially dependent on their fathers. In his case, his oldest brother had to step in and support the family. He described his first experiences on the labor market after finishing his BA as follows:

I tried to find a job in the private sector. That was at the time that I had to go back to [my village] because staying in Fez requires a lot of money, because I had to rent an apartment-it was not easy. So I had to go back home, so at least I wouldn't pay for the rent and the food. I tried my best; I applied many times to get a job but always in vein.

In comparison to other activists, Omar was lucky to actually find a job in the formal private sector, in a private high school. The salary, however, was not enough to allow him to start a family:

Then I worked as a teacher for primary school students from 2007 to 2010 .... I would work for fifteen hours per week and I would be paid 1,500 dirhams (around \$150) each month. So later on, I just made up my mind and I realized that continuing in that position wouldn't help me establish a family, because with 1,500 dirhams it is simply impossible.

Many other unemployed activists emphasize that in fact, they are working, as they struggle to get by with any job that comes up, usually in the informal sector, for example as private tutors for high school students. However, as Omar's experience in the formal sector shows, the wage there does often not allow for realizing personal goals, such as marriage. Accordingly, almost all the activists were unmarried. Some had boyfriends or girlfriends, but many of their relationships ended - or were "ended" by their own or their partners' parents-because the had not accumulated enough capital and lacked employment prospects to provide to start a household and provide for a family. Omar recounted that he quit his job in the private school to continue his studies in order to increase his chances to one day be employed on a higher rank in the public sector. 


\section{A Precarious Cycle of Lifelong Learning}

Most of the other interviewees shared similar experiences and decision-making processes. They re-enrolled, precisely because they could not find a job according to their qualifications. They affirmed that not putting their qualifications to work would solidify their precarious position and thus render their degree useless after they and their families had invested so much time and money in their education. In the meantime, their peers who had not studied at university had at least gained several years of work experience and reputation, and they often already earned more than their graduate peers would in their first job. The primary reasons for their preference for the public sector were secure pay, health insurance, social security, retirement benefits, and social prestige (Emperador Badimon 2011a). Catusse (2013, p. XV) understands the unemployed graduates' mobilization not only as the expression of a right to work that is justified by individual and collective investment in university education but also as a demand for protection in a society in which public employment offers by far the most abundant access to social rights.

Those interviewees who were holding jobs in the formal private job market would report that often they were simply not paid, or only with several months' delay, and that they had to work many hours of unpaid overtime.

\section{Protest as Part of the Transition}

At the same time, many students saw re-enrolling at the university as tantamount to preparing for several years of protests in Rabat with the Unemployed Graduates Movement. Omar explained:

Most, if not all, of the students go through this step. When they decide to apply for the master's program, they already have in mind that they will come to Rabat [to protest with the Unemployed Graduates Movement] after they get their MA because they know they will not find a job afterwards. Our university produces thousands of students, and they find themselves on the streets. They think it will be much better to get the MA and come to Rabat to demonstrate for one or two or three years ... If you are lucky you demonstrate for only one year and get a job. In the previous generations [of graduates], there are some who demonstrated only for one year and they got a job at the end.

Here, protesting after graduation seems like an almost logical step in a transition from higher education to employment, which for them was the step to financial independence, the economic key marker of adulthood. This is relevant to both 
the temporal and spatial dimensions. Like Omar, all the activists I talked to came from the rural periphery, and they lacked networks in the metropoles, where public sector recruitment was conducted. The decision to travel regularly between their home universities and protests in the capital also meant significant financial expense. Some activists regularly commuted to Rabat from as far as Oujda, on the northeastern border with Algeria, a twenty-hour train ride away. Omar, like many other activists, was co-renting rooms in two cities, one room that he shared with eleven other students in Rabat, where he would come to protest every week from Tuesday to Thursday, and another room that he shared with seven fellow students in Fez, where he was enrolled at the university.

\section{The "Arab Spring" as a Rupture: Ushering in the End of the Movement?}

At the center of the movement's discourse and framing strategy is a critique of the nepotistic and corrupt recruitment procedures in the concours examinations for public sector employment, arguing that the examiners would naturally favor their own families or admit applicants in exchange for exorbitant bribes. It might seem contradictory that, in their protests, the activists at the same time demand their own hiring without any concours or qualification exams. The protesters to a certain degree take as a given the logic of cooption in the sense that they aim for a, so to say, "meritocratic and transparent cooption," deliberately using political protest as a resource to get a job.

To link this to the discussions on temporality in youth transitions, Wyn and Woodman's (2007) critique that in many youth transition perspectives, the Baby Boomer generation often served as an implicit and generalized blueprint, against which the trajectories of young people today are measured, points to a legitimate scholarly problem. However, the Moroccan unemployed illustrate the strategic and normative leverage that comes with such a comparison from an activist's perspective. By strategically referencing the living conditions and social guarantees of the previous generation, who in this context grew up under the youth transitions regime of the development state (and its career prospects), they are defending a particular moral economy (Thompson 1971). The category of generation in this sense is also valid in that these graduates are, in the large majority of cases, the first generation of their families to have attained a university degree. What further unites them as a generational unit (Mannheim [1928] 1952 ) is the above mentioned spatial mobility pattern. All the activists I talked to came from small villages or small towns at the rural margins. Their protests thus 
also express the power relations between the periphery and the metropoles in the Moroccan kingdom.

With their 'apolitical mobilization', they obviously resist the shift to a youth transitions regime that would individualize and de-politicize the risks of unemployment, and instead refer to the old social pact under Hassan II, i.e. the promises of the development state of the Moroccanization period. Often, they directly address the king as guarantor of national unity and social justice, and activists like Omar clearly attributed the decision-making powers in this regard to the makhzen: "Those who are finding jobs for the students are not the government, but rather the deep, real rulers-I am talking about the king and his entourage. It is they who decide to employ these people."

In our first interview in 2014, Omar emphasized that the amount of time spent protesting in Rabat required to finally get a post as a civil servant was very variable: "It depends on the political situation. For us, I would say we are ((laughing)) not lucky enough because of the Arab Spring, for me it was like a curse to the unemployed movement."

In 2011, a new protest movement had formed in Morocco, motivated by the protests and revolutions in Tunisia and Egypt, and initiated mostly by young people: the 20th of February Movement (M20F), which, on that date in 2011, mobilized the largest demonstrations since independence, in fifty-three cities in Morocco. Its demands were mainly political: a democratization of the constitution, an independent judiciary, effective measures against the endemic corruption. In my interviews with $\mathrm{M} 20 \mathrm{~F}$ activists in the cities, some drew a thick line between social movements-which, in their view, pursued particularistic interests-and M20F as a political movement. Nevertheless, although sometimes marginalized, social issues were also addressed, particularly at the periphery of the M20F protests (Catusse 2013; Emperador Badimon 2019).

Omar recounts that the government, at the time headed by the Istiqlal Party, worried that the well-organized Unemployed Graduates Movement would join forces with the $\mathrm{M} 20 \mathrm{~F}$, and that this would result in a dynamic that could threaten the established order. In response, they offered the currently protesting cohorts of unemployed graduates over four thousand jobs in the public sector in exchange for not joining the M20F. However, many of the interviewees contended that the Istiqlal cadres abused the agreement and directly employed many graduates who were not even on the lists provided by the movement; they suspected that these posts were given to graduates from families better connected in the patronage networks.

What is more, when Istiqlal was ousted in the ensuing parliamentary elections in 2011, the incoming Islamist Justice and Development party finally ended the 
negotiations with the unemployed graduates. Since then, there has been no more direct employment of members of the movement. Omar recounted:

The government had never before offered that many jobs, and now it was simply too much; they could not employ more people. That's why the Arab Spring was a curse for us, for the following generations of unemployed graduates. When things began to calm down after the 20th of February, we knew the makhzen would not employ us anymore.

The movement continues protesting, but since 2011, it has not had any further success in negotiating public employment. Last time I visited Omar in 2017 in Fez, he had disengaged from the movement. Instead, he was focused on submitting his $\mathrm{PhD}$ thesis, and was struggling to get by with precarious jobs at the university and in the informal sector. Many of his fellow activists, however, were continuing to protest, together with the new cohorts of graduates that Moroccan universities had produced since 2011.

It remains to be seen if their protests will prove successful in the future, or if the 'Arab Spring' retrospectively marked the end of the Unemployed Graduates Movement, and thus the end of a key conflict in the re-configuration of the Moroccan youth transitions regime.

\section{Conclusion}

The Moroccan Unemployed Graduates Movement illustrates very vividly that transitions to adulthood are a matter of social and political struggle, and that the respective re-configurations in youth transitions regimes are subject to resistance and negotiation. Faced with the dire and precarious prospects of the largely unprotected private job market, the activists reject the individualization of the risks of their transition from higher education to the labor market. Instead, they put forward the moral economy of the old social contract of the developmental state, which would have guaranteed them transitions to adulthood characterized by a secure post in the public sector and extensive social rights.

The movement does seem very particularistic and 'apolitical' at first sight. Accordingly, it does not offer a Western audience a case for easy identification and idealization, as many of the 'Arab Spring' protesters did. Instead, the movement illustrates the constraints of long-term social mobilization under a repressive post-colonial regime. One important aspect is that the movement negotiates not only a temporal passage, but also a spatial relationship. Because the vast majority of the activists come from rural areas, either small villages or small towns at the rural margins, their protest also expresses the power relations 
between the periphery and the metropoles in the Moroccan kingdom. In terms of space, the Moroccan case and a look at its history of structural adjustment programs imposed by the IMF and World Bank also illustrates that youth transitions regimes are not limited to the framework of the nation-state, but are embedded in international power structures.

\section{Endnotes}

1. I have argued elsewhere that the focus should be placed on precariousness instead of waithood, since the latter focus suggests passivity and fails to encapsulate the often hectic schedules that characterize the daily lives of many young people in the region. Many of them do in fact work a lot, mainly in the informal market, but their jobs, as exhausting as they might be, do not generate enough income to form or maintain a family (Schwarz 2017).

2. For a better understanding of the word makhzen, which would translate directly as 'magazine', see Daadaoui (2016, pp. 41-42): "Definitions of the makhzen formulated either through interviews with politicians, or by makhzen scholars, lack a precise sense of the notion of the concept. Makhzen, for most Moroccans, is an apparatus of state violence and domination, and at the same time a system of representation of traditional royal power. Makhzen is also a system of conflict resolution controlled by the king, who dominates all fields of the social universe. It evokes fear, awe, and respect in the Moroccan political culture and refers to a patrimonial institution that has managed to adapt to the realities of modern Moroccan politics. A clear conception of makhzen is still elusive and, to capture its meaning, a cursory look at its origins and historical development seems necessary at this point." See also Daadaoui 2014.

3. The Imazighen (sg. Amazigh, "free man")—or Berbers, a term that some activists reject, since it is associated with "barbarity"-consider themselves the indigenous population of the Maghrib, those who inhabited the region before the invasion of Arab tribes. Tamazigh, a language of the Afro-Asian family that is present in Morocco in three regional varieties, is often referred to as the strongest distinguishing feature from Arab cultural identity. The Moroccan Amazigh movement, which has developed along social and cultural cleavages in the last decades, is a cultural and political nationalist movement that opposes the projects of a Pan-Arab or Islamist hegemony, and the concomitant social exclusion and marginalization of the Amazigh population (Maddy-Weitzmann 2011, 2017).

4. For an English version of the Moroccan constitution see: https://www.refworld.org/docid/3ae6b5454.html.

5. Personal communication by one activist to the author, November 2014 . 
6. All the names of interviewees were pseudonymized, and all the local and temporal references were altered, in order to protect the interviewees' identities and those of the persons that are mentioned in their life stories.

7. The Istiqlal, or Independence Party, was the first political party founded in Morocco. It has nationalist, Pan-Arab leanings and has headed the government for six legislative terms.

\section{References}

Bennani-Chraïbi, Mounia. 2000. Youth in Morocco: An indicator of a changing society. In Alienation or integration of Arab youth: Between family state and street, ed. Roel Meijer, 143-160. Richmond: Curzon.

Bogaert, Koenraad. 2018. Globalized authoritarianism: Megaprojects, slums, and class relations in urban Morocco. Mineapolis: University of Minnesota Press.

Bogaert, K., and M. EmperadorBadimon. 2011. Imagining the state through social protest: State reformation and the mobilizations of unemployed graduates in Morocco. Mediterranean Politics 16: 241-259.

Catusse, M. 2013. La question sociale aux marges des soulèvements arabes: Leçons libanaises et marocaines. Critique Internationale 61 (4): 19. https://doi.org/10.3917/ crii.061.0019.

Cohen, Shana, and L. Jaidi. 2006. Morocco: Globalization and its consequences. New York: Routledge.

Daadaoui, Mohamed. 2014. Morocco's "spring": The monarchical advantage and electoral futility. In Elections and democratization in the middle east: The tenacious search for freedom, justice, and dignity, ed. M. Hamad and K. al-Anani, 88-107. Palgrave Macmillan US: New York.

Daadaoui, Mohamed. 2016. Moroccan monarchy and the islamist challenge: Maintaining makhzen power. London: Palgrave Macmillan.

Dhillon, N., P. Dyer, and T. Yousef. 2009. Generation in waiting: An overview of school to work and family formation transitions. In Generation in waiting: The unfulfilled promise of young people in the middle east, ed. N. Dhillon and T. Yousef. Washington D.C.: Brookings Institution Press.

Elias, Norbert. 1970. What is sociology? New York: Columbia University Press.

Emperador Badimon, M. 2007. Diplômés chômeurs au Maroc : Dynamiques de pérennisation d'une action collective plurielle. L'Année Du Maghreb III: 297-311.

Emperador Badimon, M. 2009. El Movimiento de los diplomados en paro de Marruecos: Desafíos a la improbabilidad de una acción colectiva. Revista Internacional De Sociología 67 (1): 29-58. https://doi.org/10.3989/ris.2009.i1.121.

Emperador Badimon, M. 2009. Les manifestations des diplômés chômeurs au Maroc: La rue comme espace de négociation du tolérable. Genèses 3 (77): 30-50.

Emperador Badimon, M. 2011. Où sont les diplômés chômeurs? Confluences Méditerranée 78 (3): 77. https://doi.org/10.3917/come.078.0077. 
Emperador Badimon, M. 2011. Unemployed Moroccan university graduates and strategies for 'apolitical' mobilization. In Social movements, mobilization, and contestation in the middle east and North Africa, ed. J. Beinin and F. Vairel, 217-235. Stanford: Stanford University Press.

Emperador Badimon, M. 2019. From contestation to conciliation: Social networks and engagement in the unemployed graduates movement in Morocco. Social Movement Studies 18 (1): 113-129. https://doi.org/10.1080/14742837.2018.1540347.

Esping-Andersen, G.østa. 1990. The three worlds of welfare capitalism. Princeton, N.J.: Princeton University Press.

Furlong, A., D. Woodman, and J. Wyn. 2011. Changing times, changing perspectives: Reconciling 'transition' and 'cultural' perspectives on youth and young adulthood. Journal of Sociology 47 (4): 355-370. https://doi.org/10.1177/1440783311420787.

Gallie, D., and S. Paugam (eds.). 2000. Welfare regimes and the experience of unemployment in Europe. Oxford: Oxford University Press.

Hachad, N. 2017. Narrating Tazmamart: Visceral contestations of Morocco's transitional justice and democracy. The Journal of North African Studies 23 (1-2): 208-224. https:// doi.org/10.1080/13629387.2018.1400775.

Kabbani, Nader. 2019. Youth employment in the middle east and North Africa: Revisiting and reframing the challenge. Brookings. https://www.brookings.edu/research/youthemployment-in-the-middle-east-and-north-africa-revisiting-and-reframing-the-challenge/. Accessed: 25 August 2019.

Kohstall, F. 2012. Free transfer, limited mobility: A decade of higher education reform in Egypt and Morocco. Revue Des Mondes Musulmans Et De La Méditerranée, 131: 91-109. https://doi.org/10.4000/remmm.7624.

Maddy-Weitzman, Bruce. 2011. The Berber identity movement and the challenge to North African states, 1st ed. Austin: University of Texas Press.

Maddy-Weitzman, Bruce. 2017. Berbers and the nation-state in North Africa. In Oxford research Encyclopedia of African history 1, ed. Thomas Spear. Oxford: Oxford University Press (DOI: 10.1093/acrefore/9780190277734.013.105. Accessed: 8 June 2020).

Medias24. 2017. Le chômage des jeunes dans les villes dépasse $45 \%$ pour la première fois. Available online at https://www.medias24.com/MAROC/ECONOMIE/ECONOMIE/ 177926-Maroc.-Le-chomage-des-jeunes-dans-les-villes-depasse-45-pour-la-premierefois.html, checked on 5/27/2019.

Mannheim, Karl. 1952. The problem of generations. In Essays on the sociology of culture, ed. Karl Mannheim, 276-322. London: Routledge (First publication 1928).

Mendoza-Denton, N., and A. Boum. 2015. Breached initiations: Sociopolitical resources and conflicts in emergent adulthood. Annual Review of Anthropology 44 (1): 295-310. https://doi.org/10.1146/annurev-anthro-102214-014012.

Menin, L. 2019. 'Descending into hell': Tazmamart, civic activism and the politics of memory in contemporary Morocco. Memory Studies 12 (3): 307-321. https://doi. org/10.1177/1750698019836191.

Miller, Susan G. 2012. A history of modern Morocco. New York[u.a.]: Cambridge University Press. 
Nilsen, Ann, J. Brannen, and K. Chelsom Vogt. 2018. Transitions to adulthood. In Handbuch Kindheits und Jugendsoziologie, Eds. A. Lange, H. Reiter, S. Schutter, C. Steiner, 83-96. Springer Reference Sozialwissenschaften. Wiesbaden: Springer VS.

Rachik, Abderrahmane. 2010. Nouveaux mouvements sociaux et protestations au Maroc. Institut Royal des Etudes Stratégiques. https://www.ires.ma/sites/default/files/nouveaux_mouvements_sociaux_et_protestations_au_maroc.pdf?access=1. Accessed: 14 February 2014.

Roberts, K. 2007. Youth transitions and generations: A response to Wyn and Woodman. Journal of Youth Studies 10 (2): 263-269. https://doi.org/10.1080/13676260701204360.

Salehi-Isfahani, Djavad. 2008. Stalled youth transitions in the middle east: A framework for policy reform. Middle East Youth Initiative Working Paper (8). Accessed: 17 June 2011.

Sater, James N. 2007. Civil society and political change in Morocco. History and society in the Islamic world. London: Routledge.

Schwarz, Christoph H. 2017. 'Generation in Waiting' or 'Precarious Generation'? Conceptual reflections on the biographical trajectories of unemployed graduates activists in Morocco. In Neoliberalism, austerity, and the moral economies of young people's health and wellbeing, ed. P. Kelly and J. Pike, 313-332. London: Palgrave Macmillan.

Singerman, Diane. 2007. The economic imperatives of marriage: Emerging practices and identities among youth in the middle east. Middle East Youth Initiative Working Paper (6).

Singerman, Diane. 2011. The negotiation of waithood. The political economy of delayed marriage in Egypt. In Arab youth: Social mobilization in times of risk, ed. S. Khalaf and R.S. Khalaf, 67-78. London: Saqi Books.

Thompson, Edward P. 1971. The moral economy of the english crowd in the eighteenth century. Past \& Present 50: 76-136.

Vaccari, D.A. 2009. Phosphorus: A looming crisis. Scientific American 300 (6): 54-59. https://doi.org/10.1038/scientificamerican0609-54.

Vermeren, Pierre. 2006. Histoire du Maroc depuis l'indépendance. Nouv. éd. Collection Repères. Histoire 346. Paris: La Découverte.

Walther, A. 2006. Regimes of youth transitions. Young 14 (2): 119-139. https://doi. org/10.1177/1103308806062737.

Weipert-Fenner, I. 2018. Unemployed mobilisation in times of democratisation: The union of unemployed graduates in post-Ben Ali Tunisia. the Journal of North African Studies 13 (3): 1-23. https://doi.org/10.1080/13629387.2018.1535317.

White, Gregory. 2001. A comparative political economy of Tunisia and Morocco. On the outside of Europe looking in. New York: State University of New York Press.

World Bank. 2011. Poor places, thriving people: How the middle east and North Africa can rise above spatial disparities. MENA Development Report. Washington, D.C.: World Bank.

Wyn, J., and D. Woodman. 2007. Generation, youth and social change in Australia. Journal of Youth Studies 9 (5): 495-514. https://doi.org/10.1080/13676260600805713. 
Christoph Schwarz holds a doctorate in sociology, an M.A. (sociology/education), and a High School Teacher's Degree (Spanish/Civics) from Goethe-University Frankfurt (Germany). After his doctorate on adolescence in a Palestinian refugee camp, he joined the research network "Re-Configurations" at Philipps-Universität Marburg (Germany) in 2014. Here, his research focused on intergenerational relationships in social movements in Morocco and Spain, and their moral economy. Currently affiliated with the Institute for Social Research Frankfurt, he is researching the transnational movement that the Moroccan diaspora in Europe has been mobilizing in support for the Hirak protests that started in the Rif in late 2016. His general research interests include youth, intergenerational relationships, political socialization, collective memory, social movements, and migration.

Open Access This chapter is licensed under the terms of the Creative Commons Attribution 4.0 International License (http://creativecommons.org/licenses/by/4.0/), which permits use, sharing, adaptation, distribution and reproduction in any medium or format, as long as you give appropriate credit to the original author(s) and the source, provide a link to the Creative Commons license and indicate if changes were made.

The images or other third party material in this chapter are included in the chapter's Creative Commons license, unless indicated otherwise in a credit line to the material. If material is not included in the chapter's Creative Commons license and your intended use is not permitted by statutory regulation or exceeds the permitted use, you will need to obtain permission directly from the copyright holder.

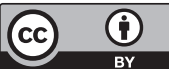

